A Short History of Sociological Thought 


\author{
Also by Alan Swingewood \\ The Sociology of Literature (co-author) \\ Marx and Modern Social Theory \\ The Novel and Revolution \\ The Myth of Mass Culture
}




\title{
A Short History of Sociological Thought
}

\author{
Alan Swingewood \\ Lecturer in Sociology, London School of Economics
}

Macmillan Education 
ISBN 978-0-333-31079-3 ISBN 978-1-349-17524-6 (eBook)

DOI 10.1007/978-1-349-17524-6

(C) Alan Swingewood 1984

Softcover reprint of the hardcover 1st edition 1984 978-0-333-31078-6

All rights reserved. For information, write:

St. Martin's Press, Inc., 175 Fifth Avenue, New York, NY 10010

Published in the United Kingdom by The Macmillan Press Ltd

First published in the United States of America in 1984

ISBN 978-0-312-72150-3

ISBN 978-0-312-72151-0 (pbk.)

Library of Congress Cataloging in Publication Data

Swingewood, Alan.

A short history of sociological thought.

Bibliography: p.

Includes index.

1. Sociology-History. I. Title

HM19. S975 $1984 \quad 301^{\prime} .09 \quad 84-40119$

ISBN 978-0-312-72150-3

ISBN 978-0-312-72151-0 (pbk.) 


\section{Contents}

Introduction 1

\section{PART I FOUNDATIONS}

\section{Origins of Sociology 7}

Human nature and social order 8

Vico: science and history 10

Montesquieu 13

The Scottish Enlightenment 17

Problems of method 20

The emergence of class 22

The dialectics of social change 24

\section{Industrialisation and the Rise of Sociological} Positivism 29

Empiricism and positivism $\quad 30$

The French Revolution and sociology 32

The concept of industrial society: Saint-Simon 36

Comte and positive science $\quad 40$

Positivism and determinism 47

Sociology, political economy and the division of labour 48

Evolutionism and sociological positivism: Mill and

Spencer 51 


\section{Marxism: A Positive Science of Capitalist} Development 59

The development of Marxism 62

Alienation of labour $\quad 63$

The concept of ideology 72

Marx's method: materialism and dialectics $\quad 80$

Class formation and class consciousness $\quad 84$

Laws of development: the problem of historical determinism 88

\section{PART II CLASSICAL SOCIOLOGY}

4 Critique of Positivism: I Durkheim 97

Durkheim and the development of sociology 97

Positivism and morality 105

Division of labour, social cohesion and conflict $\quad 112$

Anomie 117

Suicide and social solidarity 119

Functionalism, holism and political theory $\quad 125$

5 Critique of Positivism: II Social Action 129

Understanding and the social sciences: Dilthey 129

Formal sociology: Simmel and sociation 134

Understanding and the problem of method: Weber 142

Ideal types and social action 147

Religion and social action: capitalism and the

Protestant ethic 151

Capitalism and culture: Sombart and Simmel

Social action and social system: Pareto 165

\section{The Sociology of Class and Domination}

Marx's theory of domination 174

The state and class domination $\quad 176$

The theory of class: Weber 184

Capitalism, bureaucracy and democracy: Weber's theory of domination $\quad 187$ 


\section{$7 \quad$ Marxism and Sociology 196}

Marxism after Marx 196

Marxism as revolutionary consciousness: Lukács and the concept of totality 201

Culture and domination: Gramsci and the concept of hegemony 207

Marxism and the sociology of intellectuals: Gramsci 211

Lukács and Gramsci on sociology 216

Marxism and sociology: the Austro-Marxists $\quad 220$

Conclusion 222

\section{PART III MODERN SOCIOLOGY}

8 Functionalism $\quad 227$

Sociological functionalism: general features 233

The concept of system 236

Functionalism and the dialectic of social life:

Merton 241

Functionalism, social conflict and social change 246

Functionalism and stratification 251

9 Self, Society and the Sociology of Everyday

Life 254

Action theory and the concept of self: the early and later Parsons 254

Psycho-analysis and self: Freud 260

The social self: Mead and symbolic interactionism 264

Sociological phenomenology: Schutz and the reality of everyday life 270

\section{Structuralism 276}

The development of structuralism: Saussure

Post-Saussurian structuralism: language and culture $\quad 280$

Marxism and structuralism 288 
11 The Sociology of Knowledge and Culture 294

The sociology of knowledge and sociological theory 294

Mannheim: general elements of the sociology of knowledge 298

The sociology of intellectuals 302

Ideology and Utopia 305

Knowledge and mass society: Mannheim and the Frankfurt School $\quad 307$

12 Democracy, Industrialisation and Sociological Theory 312

Marxism, industrialism and democracy 313

The theory of post-industrial society $\quad 317$

Problems of legitimation 321

Theory and industrial society: convergence or diversity? 326

Further Reading $\quad 330$

Bibliography $\quad 338$

Index $\quad 350$ 


\section{HISTORY OF SOCIOLOGICAL THOUGHT}

\section{Origins}

Eighteenth-century social thought (Vico, Montesquieu, Smith, Ferguson, Rousseau)

The development of nineteenth-century sociological positivism (Comte), sociological evolutionism (Spencer) and

Marxism (Marx and Engels)

\section{Classical Sociology}

Weber, Simmel, Pareto (the tradition of verstehen sociology and critique of positivism and evolutionism)
Durkheim's critique of the positivist tradition

The development of Marxism after Marx involving a critique of materialism and evolutionism: Labriola, Gramsci, Sorel, Lukács

\section{Modern Sociology}

Phenomenological Sociology (Schutz)

Freud, Mead, Mannheim
Functionalism

Systems Theory and Action Theory (Parsons)

Structuralism 